\title{
Title:
}

\section{Use of Buscapine (scopolamine butylbromide) to facilitate specimen fixation after endoscopic submucosal} dissection

\section{Authors:}

Raúl Honrubia Lopez, Yutaka Mitsunaga, Shu Hoteya

DOI: $10.17235 /$ reed.2021.7821/2021

Link: PubMed (Epub ahead of print)

Please cite this article as:

Honrubia Lopez Raúl, Mitsunaga Yutaka, Hoteya Shu. Use of Buscapine (scopolamine butylbromide) to facilitate specimen fixation after endoscopic submucosal dissection. Rev Esp Enferm Dig 2021. doi:

$10.17235 /$ reed.2021.7821/2021.

This is a PDF file of an unedited manuscript that has been accepted for publication. As a service to our customers we are providing this early version of the manuscript. The manuscript will undergo copyediting, typesetting, and review of the resulting proof before it is published in its final form. Please note that during the production process errors may be discovered which could affect the content, and all legal disclaimers that apply to the journal pertain. 
CC 7821

Use of Buscopan ${ }^{\circledR}$ (scopolamine butylbromide) to facilitate specimen fixation after endoscopic submucosal dissection

Raúl Honrubia López ${ }^{1}$, Yutaka Mitsunaga ${ }^{2}$ and Shu Hoteya ${ }^{2}$

${ }^{1}$ Gastroenterology Section. Hospital Universitario Infanta Sofía. San Sebastián de los Reyes, Madrid. Spain. ${ }^{2}$ Deparment of Gastroenterology. Toranomon Hospital. Tokyo, Japan

Correspondence: Raúl Honrubia López. Sección de Aparato Digestivo. Hospital Universitario Infanta Sofía. Paseo de Europa, 34. 28703 San Sebastián de los Reyes, Madrid. Spain

e-mail: raul.honru@gmail.com

Keywords: Endoscopic submucosal dissection. Stomach. Buscopan ${ }^{\circledR}$.

Dear Editor,

Endoscopic submucosal dissection (ESD) is a technique used for the en-bloc resection of early neoplastic lesions in the gastrointestinal tract. A step that must be carried out after excision is the pinning down of the specimen on a support plate, such as a cork board, to avoid artifacts due to tissue contraction (1). After ESD, lesion borders usually curl up from contraction, hence this procedure must be carefully performed to prevent damaging the specimen. Recently, Nishizawa $T$ et al. (2) reported that dropping adrenaline onto the lesion results in edge relaxation, which facilitates fixation (2). However, the use of other drugs, such as Buscopan ${ }^{\circledR}$, that induce gastrointestinal smooth muscle relaxation with potentially similar effects has not been described. 
Below, two ESD specimens from two different institutions are shown. These specimens correspond to gastric lesions (Fig. 1A-B). Buscopan ${ }^{\circledR}$ was applied on their surface and the edges became relaxed, thus facilitating stretching (Fig. 1C-D) and fixation.

In conclusion, the use of Buscopan ${ }^{\circledR}$ may help in the processing of excised lesions by facilitating pinning out and reducing the risk of damaging specimens.

Conflict of interest: the authors declare no conflict of interest.

\section{REFERENCES}

1. Pimentel-Nunes $P$, Dinis-Ribeiro $M$, Ponchon $T$, et al. Endoscopic submucosal dissection: European Society of Gastrointestinal Endoscopy (ESGE) Guideline. Endoscopy 2015;47(9):829-54. DOI: 10.1055/s-0034-1392882

2. Nishizawa $\mathrm{T}$, Kinoshita $\mathrm{S}$, Mori $\mathrm{H}$, et al. Use of adrenaline for specimen fixation after endoscopic submucosal dissection. Endoscopy 2019;51(8):E204. DOI: 10.1055/a-0866-9302 

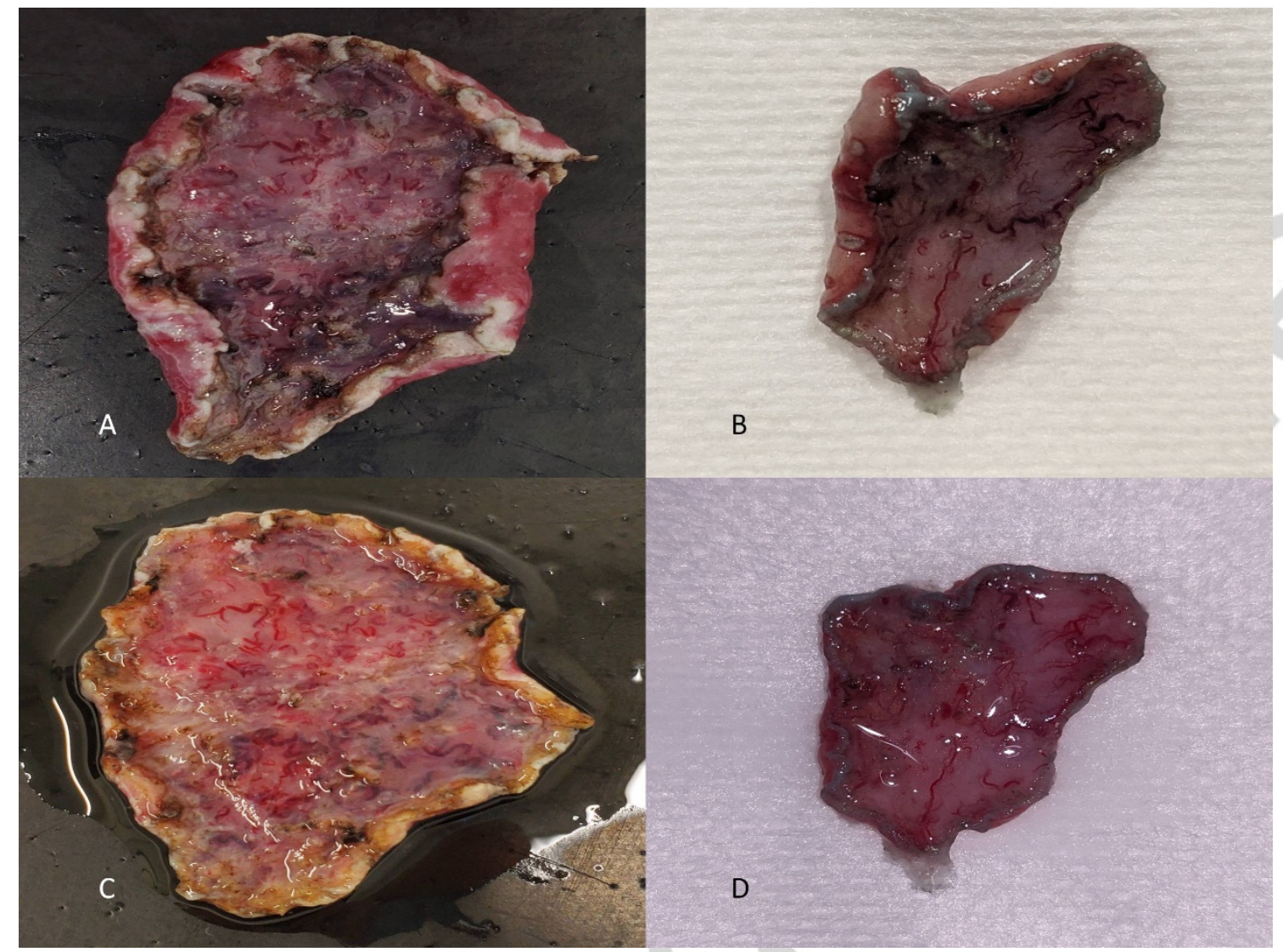

Fig. 1. A-B: gastric lesions after ESD, their curled up borders are clearly seen. C-D: after Buscopan ${ }^{\circledast}$ administration edges become relaxed and stretching is feasible. 